\title{
Erratum: Reflections on science advisory systems in Canada
}

Remi Quirion, Arthur Carty, Paul Dufour and Ramia Jabr

Correction to: Palgrave Communications (2016) 2, Article number: 16048. doi:10.1057/palcomms.2016.48; Published 2 August 2016; Updated 13 September 2016

The affiliations of the authors Arthur Carty and Paul Dufour were listed incorrectly; these have now been corrected and read as follows:

Arthur Carty-University of Waterloo, Canada

Paul Dufour-University of Ottawa, Canada

The article has been corrected online.

\footnotetext{
(c) (i) This work is licensed under a Creative Commons Attribution 4.0 International License. The images or other third party material in this article are included in the article's Creative Commons license, unless indicated otherwise in the credit line; if the material is not included under the Creative Commons license, users will need to obtain permission from the license holder to reproduce the material. To view a copy of this license, visit http://creativecommons.org/licenses/by/4.0/
} 